\title{
Natural breeding of freshwater apple snail Pila globosa (Swainson) in pond and aquarium
}

\author{
RAKHI DAS, MD. SHARIFUL ISLAM, MOHAMMAD MONIRUZZAMAN ${ }^{1}$ \\ AND KHAN KAMAL UDDIN AHMED* \\ Bangladesh Fisheries Research Institute, Shrimp Research Station, Bagerhat 9300, Bangadesh \\ ${ }^{1}$ Bangladesh Fisheries Research Institute, Mymensingh 2201 \\ *Email: kkuabd@gmail.com
}

\begin{abstract}
The freshwater apple snail, Pila globosa is one of the most abundant and commercially valued molluscs. Over exploitation of $P$. globosa for prawn farming is an alarming condition. The present study is aimed at elucidating the breeding behavior and reproduction process of $P$. globosa. The natural breeding experiment was conducted in two ponds- a 52 decimal pond in Gopalgonj sadar and a 40 decimal pond in Kotalipara. The ponds were prepared by applying lime at the rate of $3 \mathrm{~kg} / \mathrm{decimal}$ and then filled up with water up to $30 \mathrm{~cm}$. Wild snails were stocked at the rate of $600 \mathrm{no} . /$ decimal. Organic compost (cow-dung, mustard oilcake and urea at the ratio of 1:1:0.5at the rate of $2.5 \mathrm{~kg} /$ decimal respectively) spread throughout the pond. Several male and female specimens were collected from experimental gher and brought to the laboratory aquarium to observe their breeding behavior. At the bottom of aquarium substrate like plastic bottle, marbel, artificial tree etc. were provided for egg laying. Breeding involves three processes: copulation, fertilization and laying. Copulation occurs in water on moist land and it takes about 3-4 hrs, then both separated. Fertilization is internal in P. globosa. Egg laying started 2 or 3 days after copulation. They lay eggs in sheltered places or moist land near water in the dyke. A single female lays eggs average $387.89 \pm 167.65$ no. per clot at a time. The time elapsed between the first and the last hatchings ranged from 6 to 25 days and for $80 \%$ of the 5 egg masses were studied. Considering all the eggs in the egg masses $(n=1856)$ more than $60 \%$ of the eggs hatched within 13 days of the first hatching. It needs about 25 days for full clot to be hatched. In the laboratory condition hatching success was observed about $80 \%$.
\end{abstract}

Keywords: Snail, Pila globosa, Breeding

\section{Introduction}

There are about 450 species of snails in Bangladesh (Gain 1998), of which freshwater apple snail, Pila globosa is one of the most abundant and commercially valued molluscs. It is widely distributed in all types of temporary and permanent water bodies, such as ponds, canals, ditches, beels, haors and baors (Nath et al. 2008). Snail plays an important role in the ecosystem in maintaining healthy aquatic environments by acting as a biofilter, a pre-requisite for conserving biodiversity (Jahan et al. 2001). Saha (1998) identified 29 groups of tribal people that consume snail flesh. Snail meat is instead more extensively used in freshwater prawn (Macrobrachium rosenbergii) farming in the south-western part of the country (Baby et al. 2010, Nahid et al. 2013). The average application of snail meat to prawn ponds is $0.3 \mathrm{~kg} / \mathrm{decimal} / \mathrm{day}$ during June to October (Ahmed et al. 2008). Snail meat is also utilized as supplementary feed in indigenous catfish (Clarius batrachus) farms and domestic ducks throughout most of the year (Banglapedia 2006). Snail shell is used to produce lime and animal feed additive due to its rich $\mathrm{CaCO}_{3}$ content (Nath et al. 2008). Though P. globosa is amphibious, water is essential for all of its biological activities except egg lying. Thus, it passes its life mostly in water. The snails undergo aestivation by November or December when the field becomes dry, while those living in pond 
RAKHI DAS et al.

remain active as long as water is available (Raut 1984). However, recently, as a result of excessive fishing pressure and lack of regulations, drastic reductions of wild snail populations have occurred in Bangladesh (Nath et al. 2008). Regulating the collection of snails is difficult as it is an essential livelihood for the poor (Jahan et al. 2001). After collection, snails are distributed to prawn farmers in the south-western regions through a line of middlemen. Although Ahmed (2001) described the value chain of snails from Chanda Beel of Gopalganj to Bagerhat district in 1999 and Nath et al. (2008) within Khulna in 2006, the chain between Chanda Beel and Khulna district has, to date, remained unreported. Generally, P. globosa and Bellamya bengalensis are harvested commercially as feed to the shrimp farm of Bagerhat areas.

Traditional piscine based aquaculture practices are very much traditional in Bangladesh whereas, in many Asian countries, there are diverse aquaculture practices going on with nonpiscine species. Among the non- piscine species, mollusk culture is very common in many parts of Asia. In Bangladesh till today nobody has become interested in snail farming. Though snail capturing and its utilization as human food, poultry feed and in large scale as supplementary feed for prawn farms are lavishly going on. Specially, over exploitation of $P$. globosa for prawn farming is in an alarming condition. The ecologically and economically important such a biological resource will become extinct within a very short time if no steps are taken to reproduce of this species immediately. Considering the above facts, the present research plan attempt is taken to identify the breeding behavior and culture potential of this species for ensuring the sustainable natural population and stocking of $P$. globosa.

\section{Materials and Methods}

Selection of the experimental ponds: Two farmer's ditches were selected for this research. A total area of 52 decimal in Gopalgonj sadar Upazilla and 40 decimal in Kotalipara Upazilla of Gopalgonj District, Bangladesh was selected for breeding of snail in natural habitat (Fig. 1).

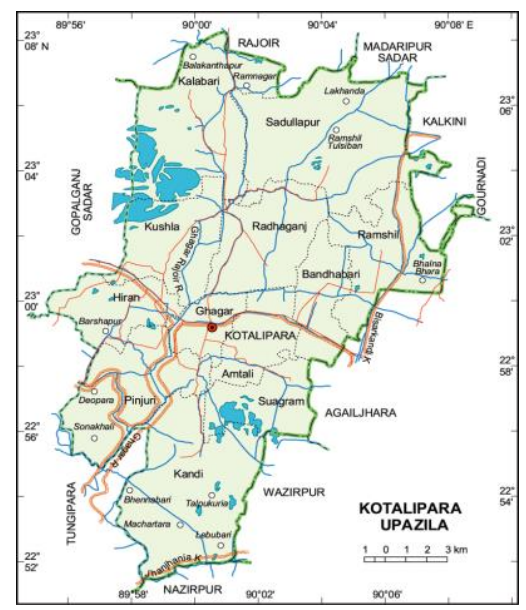

Fig. 1. Maps of experimental site. 
Fencing and sanitizing. Bamboo split fence locally called 'bana' along with fine meshed nylon net and bamboo was used to fence on the dikes around the gher to prevent the snail escaping. Dikes were maintained as snail lay eggs on the locally called (Ail) in rice field. Aquatic vegetation planted on dike for ensuring proper breeding ground for snail.

Pond preparation: The ponds were dried before the stocking of mature snails. The excessive bottom mud was removed from the pond. Liming was done at the rate of 1-1.5 kg/decimal. Then pond was filled up with water up to 1 foot and then compost was spreaded throughout the pond during noon. Compost was prepared by mixing cow dung, mustard oilcake and urea at the ratio of $1.0 \mathrm{~kg}, 1.0 \mathrm{~kg}$ and $0.5 \mathrm{~kg} / \mathrm{decimal}$ respectively. The mixing compost was manually kept in water for three days and added to the pond water. After 3-4 days, pond was filled up with 3-4 $\mathrm{ft}$ water and then snails were released.

Selection and stocking of brood stock. Sexually mature Wild snails, average weight $45.09 \pm 3.11 \mathrm{~g}$, was collected from the Chaitarbari beel, Boalmari Upazilla, Faridpur Zilla as initial breeding stock. Snails normally start to breed at wet season. Wild snails were stock in the peak season and fatten them in captivity in the off season. During May mature snails were stocked at the rate of 600 nos./decimal in the experimental ponds.

Feeding of snail: At 15 days of interval, compost was provided to the pond for satisfactory growth and breeding of snails. The ratio of composition of compost with cow dung, mustard oil cake and urea was 2.5:2.5:1. For one decimal area of ponds required ingredients were $600 \mathrm{~g}$. The mixture of compost was kept in water for 3 days and then divided into three parts and broadcast into pond. After application of the compost, red earthworms and other Chironomid larvae were observed on pond bottom having samples of mud. Those small red earthworms were used as food for snails. Moreover, by applying compost, plankton populations were developed in the pond which was used as feed by snail. For snail (10\%-16\%) protein containing food and Calcium Carbonate $(30 \%-40 \% \mathrm{Ca})$ in the form of limestone flour was supplied. Young snails prefer tender leaves and shoots while mature snails increasingly feed on detritus: fallen leaves, rotten fruit and humus. The feeds recommended for snails are sweet potato, soyabean, fish meal, Leaves, Fruits, household waste, market waste and banana leave etc. Food was salt free, given morning and night only.

Water quality parameters determination: Physico-chemical parameters viz., Water Temperature $\left({ }^{\circ} \mathrm{C}\right)$, Dissolved Oxygen $(\mathrm{mg} / \mathrm{l})$, Moisture, $\mathrm{pH}$, Ammonia $(\mathrm{mg} / \mathrm{l})$, Carbon Dioxide $\left(\mathrm{CO}_{2}\right)$, Hydrogen Sulfide $\left(\mathrm{H}_{2} \mathrm{~S}\right)$, and Nitrite were monitored between 8.30 to 9.30 am using Celsius thermometer, portable dissolved oxygen meter (Oakton), a portable pH meter (HI 8424, Hanna Instruments, Portugal), portable moisture meter respectively. Ammonia, $\mathrm{CO}_{2}, \mathrm{H}_{2} \mathrm{~S}$ and Nitrite were determined using $\mathrm{HACH}$ Kit. After having water quality report if need necessary action was taken.

Snail breeding in the laboratory: In order to examine, the details of the process of copulation, several male and female specimens were collected from experimental pond and brought to the laboratory. At the bottom of aquarium substrate like plastic bottle, marbel etc. were provided for egg laying. They were kept in an aquarium where they copulate either floating in water or 


\section{RAKHI DAS et al.}

attached to the glass side of the aquarium. Details of copulation were observed, recorded. Photographs were taken of the copulating pairs in situ. During courtship, dissect female snails and observed fertilization process of snail.

Water management. Water temperature $\left(22\right.$ to $\left.28^{\circ} \mathrm{C}\right)$ was maintained by sheltering in some places by aquatic vegetation. As the experiment conducted in the beel sometimes water level was maintained by supplying water through irrigation system. In case of aquarium clean environment was maintained by frequent change of water. After hatching tiny small snail was transferred to separate aquarium. Fish net was used to scoop out any dead organisms

\section{Results and Discussion}

Influence of temperature and moisture on breeding: Temperature is a major factor that influences the activities of snails. We found an average temperature of $30 \pm 2.89^{\circ} \mathrm{C}$ in ponds which is very congenial for snails (Table I). Aquatic vegetation on the water helps to maintain water temperature in a suitable range. Snail requires lower and moderate temperature for normal feeding and body functions. Okafor (2001) stated that temperature ranges between $23-28^{\circ} \mathrm{C}$ are suitable for snails' growth and development. During hotter periods with high ambient environmental temperature, snails may experience heat stress. Heat stress poses a serious economic threat to snails' population and snails under domestication. Okafor (2001) also stated that snails hibernates and aestivation especially during dry hot unfavorable seasons. Air, environmental and noise pollutions (Ebenso and Ologhobo 2009) affects snails. Estebenet and Cazzaniga (1992) showed that the life cycle of $P$. canaliculata changes from annual and semelparous (one reproductive period in the lifespan) at $25^{\circ} \mathrm{C}$ to tetra-annual and iteroparous (more than one reproductive period) at room temperature $\left(9-29^{\circ} \mathrm{C}\right)$. The optimum temperature range for Asolene platae is $25-30^{\circ} \mathrm{C}$; temperatures above $35^{\circ} \mathrm{C}$ increase mortality, whereas below $20^{\circ} \mathrm{C}$ activity and growth almost stop (Tiecher et al. 2015)

Table I. Water quality parameters of experimental pond/ditches

\begin{tabular}{|l|c|}
\hline Parameters & Mean value \pm SD \\
\hline Temperature & $30 \pm 2.89{ }^{\circ} \mathrm{C}$ \\
\hline Moisture & $82 \pm 4.69 \%$ \\
\hline $\mathrm{pH}$ & $8.04 \pm 0.30 \mathrm{mg} / 1$ \\
\hline $\mathrm{DO}$ & $4.78 \pm 1.64 \mathrm{mg} / 1$ \\
\hline $\mathrm{CO}_{2}$ & $1.3 \pm 0.31 \mathrm{mg} / \mathrm{l}$ \\
\hline Ammonia & $0.021 \pm 0.003 \mathrm{mg} / 1$ \\
\hline Nitrite & $0.14 \pm 0.05 \mathrm{mg} / 1$ \\
\hline Hydrogen sulfide & $0.02 \pm 0.005 \mathrm{mg} / 1$ \\
\hline
\end{tabular}

Snails enjoy moist and cooler environments, which is usually achieved when it rains, the atmospheric air become moist with high relative humidity. If the air is drier and hot, for longer periods, snails may dry up and die or hibernate. Average moisture level was found $82 \pm 4.69 \%$ which is also congenial for snails (Table I). The average $\mathrm{pH}$ level $(8.04 \pm 0.30 \mathrm{mg} / \mathrm{l})$ also found 
suitable for fish or live animals. According to Swingle et al. (1969) pH 6.5 to 9.0 is suitable for pond culture which agreed to the present study (Table I). Ammonia contents in pond/ditches found $0.021 \pm 0.003 \mathrm{mg} / 1$ (Table I). The amount of ammonia-nitrogen obtain in this study is comparatively lower than the result reported by Dewan et al. (1991). However, the present level of ammonia content in the experimental ponds is not lethal to the fishes or live animals. The average value of DO in present experiment were found $4.78 \pm 1.64 \mathrm{mg} / 1$ (Table I). Rahman et al. (1982) have reported that dissolved oxygen content of a productive pond should be $5.00 \mathrm{mg} / 1$ or more. From all this physico-chemicals data it was proved that pond/ditches environment should be maintained so that it could be very much congenial for snails breeding. Like temperature and moisture others water quality parameters has great impact on breeding of snail. Patnaik and Ray (1968) mentioned that turbidity of water due to suspended organic matter plankton or silt was the second limiting factor for Lymneae auricularia. Saha (1998) found that abundance of $P$. globosa was positively correlated with dissolved oxygen. Raut (1969) stated that development of Lymneae luteola was highly influenced by $\mathrm{pH}$ of water and beyond the ranges between 6.0 and 9.5 eggs of snail are not hatched.

Sexual dimorphism: Snails have a striking appearance, but their reproductive habits are uncommon. One of the keys to snail survival through time is the characteristics of their reproduction process. In P. globosa, as in all Ampullariidae, the sexes are separate and the males are generally much smaller with the body-whorl of the shell less swollen. Male organs consist of (i) the testis with its fine vasa efferentia, (ii) vas deferens with the vesicula seminalis, and the terminal glandular part of the vas deferens, (iii) the hypobranchial gland, and (iv) the penis and its sheath (Fig. 2). The generative organs of the female consist of (i) the ovary with its numerous minute ducts, (ii) the main oviduct, (iii) the receptaculum seminis, (iv) the uterus, (v) the vagina, and (vi) the hypobranchial gland with the rudimentary copulatory apparatus (Fig. 2).

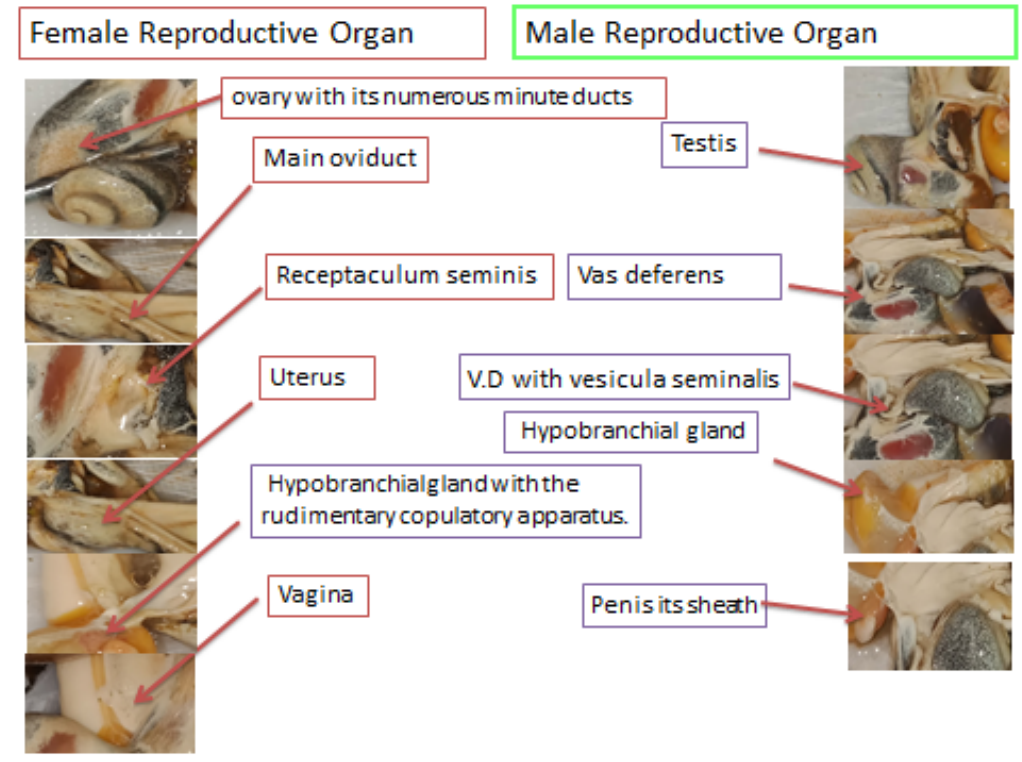

Fig. 2. Sexual dimorphism of apple snail. 


\section{RAKHI DAS et al.}

Reproduction in snails: The female creeps along the glassside of the aquarium and comes up near the surface of the water, while the male mounts on the female, takes up its proper position and inserts its penis-sheath and penis into the mantle-cavity of the female. The whole process can be easily observed through the glassside of the aquarium. Pairing specimens either floating in water or lying on the ground can be picked up and their copulatory mechanism examined. The mouth of the shell of the female is easily kept open by pressing the operculum against the shell with the thumb of the left hand and by doing so, the white or light blue penis-sheath is easily seen inserted into the mantle-cavity of the female.

Courtship: Before the intercourse, both partner approach to start the courtship process consisting of a series of movements and attitudes that will finish or not in the mating. The entire process can last as little as 2 hours or as long as 12 hours. In this study, courtship of snails was found to be $4.43 \pm 0.98$ hours. To find a partner, they primarily rely on their sense of smell and touch, as their visual capacity is poorly developed and devoid of hearing. They can recognize chemicals in the air that communicate the receptivity of some other snail nearby. Breeding involves three processes: copulation/matting, fertilization and laying.

Copulation/Mating: During copulation of $P$. globosa in water lasted for 3 hours where its head and foot generally extended, feeds freely on water-weeds in the pond or the aquarium, but the male keeps its head generally retracted and puts out only its penis-sheath and inserts it into the mantle-cavity of the female (Fig. 3). Male and female Pila come together facing each other. According to Bahl (1928) findings the penis of the male is expanded and gets attached to the genital papilla by its base. Then the penis and its sheath were inserted into the mantle cavity of the female. The tip of the penis was put into the female genital aperture and spermatozoa were transferred through the vagina into the receptaculum seminis. While the penis-sheath can be seen enveloping the female generatIve aperture, the role of the penis in the process and the exact mode of transmission of the spermatic fluid from the male generative aperture to the female opening cannot be made out by a direct observation of the copulating pairs. For these at first broke portions of the shell of several males in order to expose the penis-sheath and kept such males with females in an aquarium. The shells of the females were also broken so as to observe more easily the terminal portion of the vagina and the female generative aperture. Then the exact mode of transference of the seminal fluid from the male genital aperture to the base of the penis and also the insertion of the penis into the vagina. Another attempts were then made to kill and fix rapidly copulating pairs in sexual congress. The mating process of snails starts on reaching sexual maturity, followed by finding the right partner, copulating, locating and creating a place to deliver the eggs, hatching of the eggs and ending with the development of small snails. Copulation occurs in water on moist land and takes average $3.57 \pm 0.53$ hours.
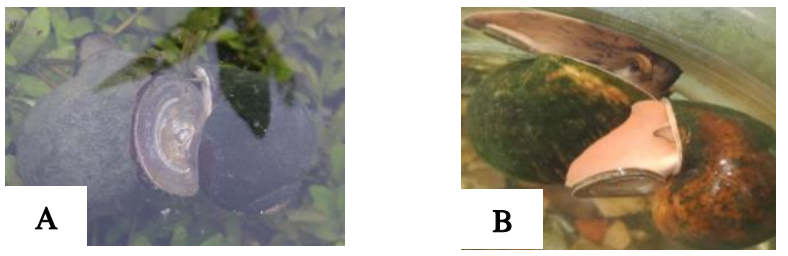

Fig. 3. Copulation of snails in pond (A) and aquarium (B). 
Fertilization: Eggs were fertilized in the uterus and oviposition starts a day or two later. The fertilized eggs were laid in masses in moist earth near ail particularly in dam areas so that moisture content of eggs remain suitable condition to be hatched. Fertilization is internal in Pila (Fig. 4). After fertilization, the eggs go through a process of growth inside the snail, until they are ready to be delivered. Eggs started laying 2 or 3 days after copulation. They lay eggs in sheltered places or moist land near water in the dike. A single female lays eggs average $387.89 \pm 167.65$ no. per clot at a time (Fig. 5). Eggs are rounded, about the size of the ea seeds and covered by whitish shell. According to Tiecher et al. (2013) a mature Asolene platae female laid on average $20.61 \mathrm{egg}$ masses during its whole lifespan, for a sum total of 1429.9 eggs. The number of eggs is lower than those of Pomacaea.maculata (2,066 eggs per egg mass with 16-18 egg masses per warm period (Barnes et al. 2008) and Pomacaea canaliculata (4407-4641 eggs per female (Estebenet and Martin 2002), but the number of egg masses appears similar (19-28 on average).

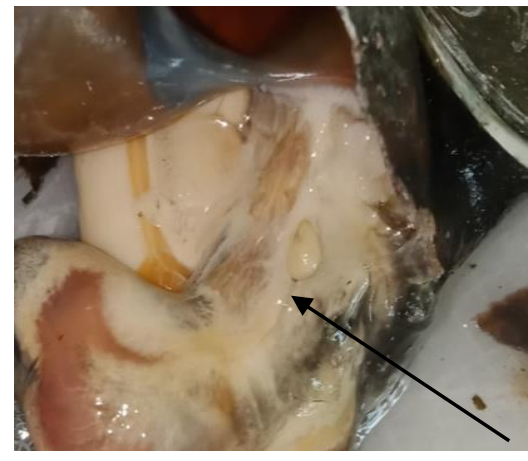

Fig. 4. Internal fertilization by apple snail.
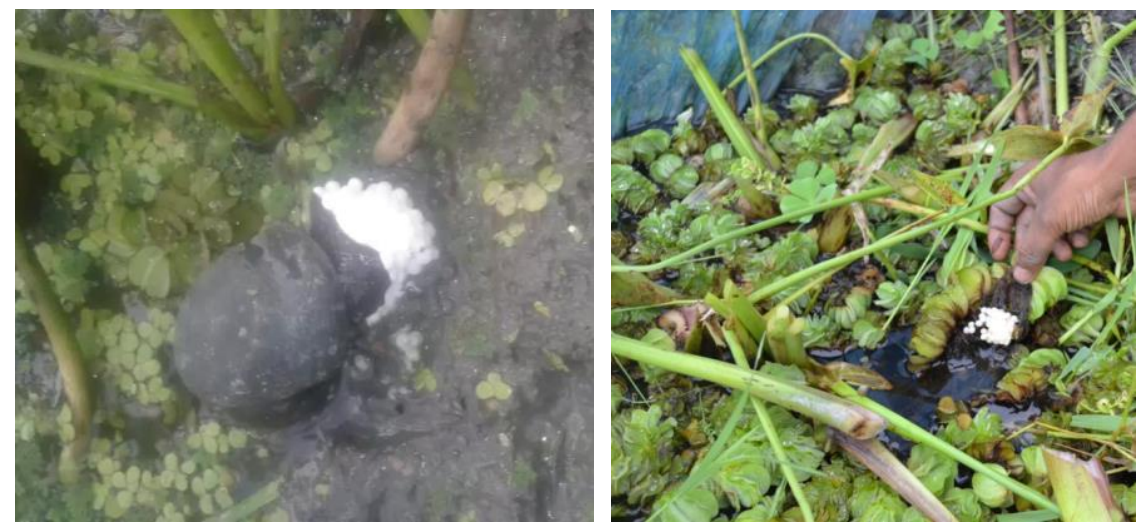

Fig. 5. Egg laying by apple snail.

Observation of hatching in aquarium: Fertilized eggs collected from field needed max. 25 days for full clot to be hatched. In laboratory condition $80 \%$ of $P$. globosa eggs found fertile which matches with finding of Gamarra-luques et al. (2013) the Pomacea canaculata another apple 


\section{RAKHI DAS et al.}

snail species where spawning behaviour begins 2 weeks later and the majority of eggs ( $>80 \%)$ in the first deposited egg clutches are fertile. According to Tiecher et al. (2015) the survivorship curves of $A$. platae showed a high mortality (63\% on average).

Embryonic and larval development: According to the Tiecher et al. (2013) during development, the inner cavity of the perivitellus gradually increases in size and the rubbery portion decreases in thickness, apparently due to the feeding activity of the embryo. In the first stages of development, the embryo moves on the internal surface by ciliary action but later begins to crawl on it and the buccal massis continuously moving. At the time of hatching, the perivitellus has been totally consumed by the embryo that crawls and grazes continuously on the inner layer of the egg capsule. The calcite elements present inside the egg disappeared soon after the start of embryo development, but those on the jelly matrix lasted up to the time of hatching and beyond. The findings of Tiecher et al. (2015) match with present observation. The time elapsed up to hatching of the first egg in each egg mass (mean \pm SD) was $9.80 \pm 2.19$ days and ranged from 6 to 25 days .Hatching within each egg mass was highly asynchronous: the time elapsed between the first and the last hatchings ranged from 6 to 25 days and for $80 \%$ of the 5 egg masses was studied. Considering all the eggs in the egg masses $(n=1856)$, more than $60 \%$ of the eggs hatched within 13 days of the first hatching of each egg mass. The recently emerged hatchling has the appearance of a miniature snail with tentacles, eyes, ctenidium, osphradium, foot, operculum, and shell. Under laboratory conditions, the jelly of the egg mass is the first food taken by the hatchlings. Larval development of snails also observed in aquarium (Fig. 6).
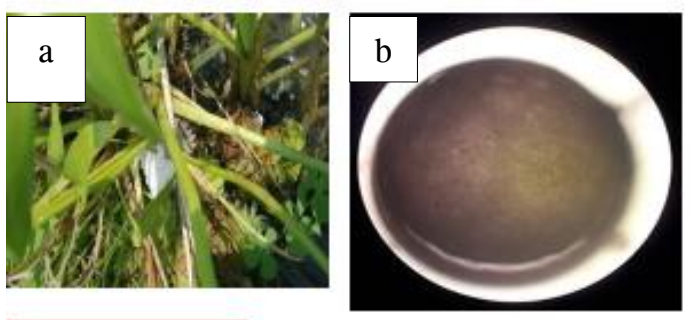

Snail Egg mass

Fertilized egg of just after spawning
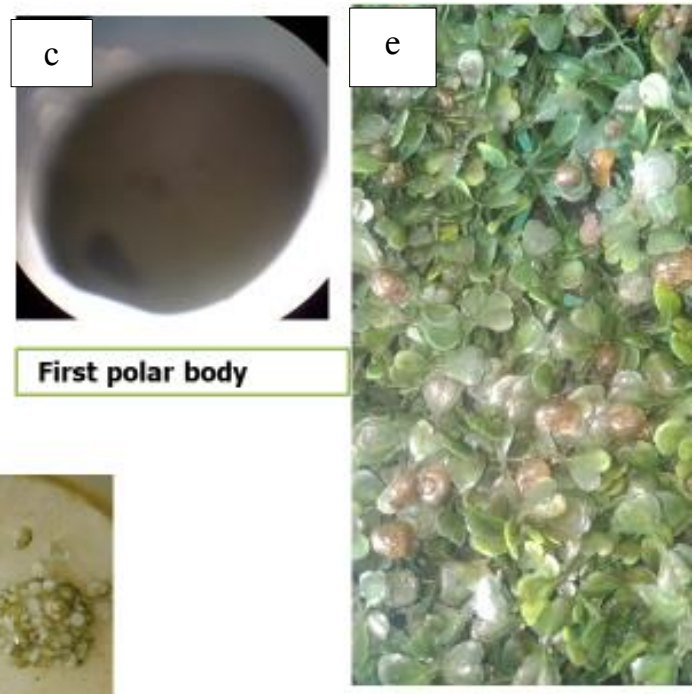

Hatched after 13

days

First polar body

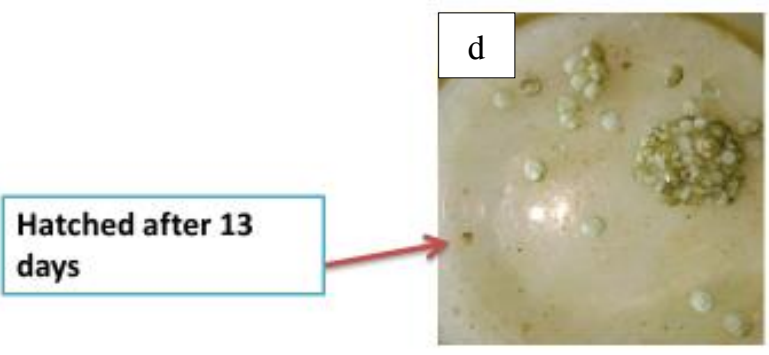

Tiny snail aged 14

days

Fig. 6. Larval development of snail (a. in pond; b. under microscope; c. under microscope; d. in beaker; e. in aquarium) 
The present investigation is a preliminary work on examining the possibilities of successful snail breeding by creating artificially natural environment, breeding biology, culture potentiality and further research on these aspects is on-going.

Acknowledgements: Authors thankfully acknowledge the Director General of BFRI for financial and technical assistance of this research project under development project "Conservation, Propagation \& Culture of Mussels and Snails in Bangladesh"'.

\section{Literature Cited}

Ahmed, N., 2001.Socio-economic aspects of freshwater prawn culture development in Bangladesh. PhD dissertation. Institute of Aquaculture, University of Stirling, Scotland, UK. 346 p

Ahmed, N., H. Demaine and J.F. Muir, 2008. Freshwater prawn farming in Bangladesh: history, present status and future prospects. Aquac. Res., 39: 806-819.

Baby, R.L., I. Hasan, K.A. Kabir and M.N. Naser, 2010. Nutrient analysis of some commercially important molluscs of Bangladesh. J. Sci. Res., 2 (2): 390-396.

Bahl, K.N., 1928 On the reproduction and development of Pila globosa (Swainson). Part I, copulation and oviposition. Mem. Indian Mus., 9: 1-11.

Banglapedia, 2006. National encyclopedia of Bangladesh. Retrieved September 23, 2011 from http://www.banglapedia.org/httpdocs/HT/S 0437.HTM.

Barnes, M.A., R.K. Fordham, R.L. Burks, and J.L. Hand, 2008. Fecundity of the exotic apple snail, Pomacea insularum. J. North Am. Benthologic. Soc., 27: 738- 745.

Dewan S., M.A. Wahab, M.C.M. Beveridge, M.H. Rahman and B.K. Sarker, 1991. Food selection, electivity and dietary overlap among planktivorous Chinese and Indian major carp fry and fingerlings grown in extensively managed, rain fed ponds in Bangladesh. Aquac. Fish. Manage, 22: 277-294.

Ebenso, I.E. and A.D. Ologhobo, 2009. Effects of air, environmental and noise pollutions on snails. Bull. Environ. Cont. Toxicol., 81: 513-515.

Estebenet, A.L. and N.J. Cazzaniga, 1992. Growth and demography of Pomacea canaliculata (Gastropoda: Ampullariidae) under laboratory conditions. Malacologic. Rev., 25: 1- 12.

Estebenet, A.L. and P.R. Martín, 2002. Pomacea canaliculata (Gastropoda: Ampullariidae): life-history traits and their plasticity. Biocell, 26: 83-89.

Gain, P., 1998. Chanda beel: shrimps attacks snails and environment. In: P. Gain (ed.), Earth Touch. The Society for Environment and Human Development, Dhaka, Bangladesh. 17-20.

Gamarra-luques. C, M. Giraud-billoud and A. Castro-vazquez, 2013. Reproductive organogenesis in the apple snail Pomacea canaculata (Lamarck, 1822), with reference to the effects of xenobiotics. $J$. Mollus. Stud., 79(2): 147-162. doi.org/10.1093/mollus/eyt011

Jahan, M.S., M.S. Akter, M.M. Sarker, M.R. Rahman and M.N. Pramanik, 2001. Growth ecology of Pila globosa (Swainson) (Gastropoda: Pilidae) in simulated habitat. Pakistan J. Biol. Sci., 4 (5): 581584.

Nahid, S.A.A., P.J.G. Henriksson and M.A. Wahab, 2013. Value-chain analysis of freshwater apple snail (Pila globosa) used for on-farm feeds in the freshwater prawn farming sector in Bangladesh. Int. J. Agril. Res. Innov. Tech., 3 (2): 22-30.

Nath, R.D., M.L. Rahi, G.S. Hossain and K.A. Huq, 2008. Bangladesh status of freshwater snail in Khulna district. Bangladesh Res. Pub. J., 1 (4): 337-347.

Okafor, F.C. 2001. Edible land sail: A manual of breeding management of Achatima achatina. Simarch Publizahas, Lagos. 72 p.

Patnaik, M.M. and S.K. Ray, 1968. Studies on geographical distribution and ecology of Lymnaea auricularia var rufescens the intermediates host of Faciola gigantica in Orissa. Indian J. Vet. Sci., 32: 3 


\section{RAKHI DAS et al.}

Rahman, M.S., M.Y. Chowdhury, A.K.M.A. Haque and M.S. Haq, 1982. Limnological studies of four ponds. Bangladesh J. Fish., 2(5): 25-35.

Raut, S.K., 1984. On the egg laying behaviour of the apple snail Pila globosa (Swainson) (Mollusca: Gastropoda). Sci. Cult., 50(6): 198-199.

Raut, S.K., 1989. Laboratory rearing of medically and economically important molluscs. M.S. Jairajpuri (ed.) Snails, Flukes and man, Zoological Survey of India, Calcutta, 81-88.

Saha, B.K., 1998. Ecology and bio-eonomics of the freshwater edible snails of Bangladesh. PhD dissertation. Rajshahi University, Bangladesh. 162 p.

Swingle, H.S., 1969. Standardization of chemical analysis for waters and pond mud. FAO. Fish. Res. 4: 397-421.

Ticher, M.J., S. Burela and P.R. Martin, 2013. Mating behavior, egg laying, and embryonic development in the South American apple snail Asolene pulchella (Ampullariidae, Caenogastropoda). Invert. Reprod. Dev., 58: 13-22. DOI:10.1080/07924259.2013.793624

Tiecher, M.J., M.E. Seuffert and P.R. Martin, 2015. Thermal biology of the South American apple snail Asolene platae (Caenogastropoda: Ampullariidae). Malacologia, 58: 233-243.

(Manuscript received: 12 March 2020) 